Chirurgia (2019) 114: 467-474

No. 4, July - August

Copyright@ Celsius

http://dx.doi.org/10.21614/chirurgia.114.4.467

\title{
A Study Comparing Outcomes of Appendectomy between HIV-Infected and HIV-Negative Patients
}

\author{
Sanju Sobnach', Chikwendu Ede², Gerhard Van Der Linde ${ }^{3}$, Juan Klopper ${ }^{1}$, Ahmed Bhyat ${ }^{4}$, Delawir Kahn² \\ 'Department of Surgery \& Division of General Surgery, Groote Schuur Hospital and University of Cape Town, Republic of South Africa \\ 2Department of Surgery, University of Witwatersrand, Johannesburg, Republic of South Africa \\ ${ }^{3}$ Department of Anatomical Pathology, Kimberley Hospital Complex, Republic of South Africa \\ ${ }^{4}$ Department of General Surgery, Kimberley Hospital Complex, Republic of South Africa
}

Corresponding author:

Sanju Sobnach, MD

Department of Surgery

Division of General Surgery

Groote Schuur Hospital

(J45, Old Main Building)

Anzio Road

Observatory 7935

Cape Town

South Africa

Email: sanjusobnach@yahoo.com

Abbreviations:

HIV - Human Immune Deficiency Virus AIDS - Acquired Immune Deficiency Syndrome

GIT - Gastrointestinal

KS - Kaposi's Sarcoma

Received: 29.12 .2017

Accepted: 17.02.2018

\section{Rezumat}

Studiu privind compararea rezultatelor apendicectomiei la pacientii infectati cu HIV versus pacienții neinfectati

Context: Prevalența crescută a virusului imunodeficienței umane (HIV) a dobândit o dimensiune nouă în managementul şi rezultatul intervențiilor chirurgicale în Africa de Sud. Cu toate acestea, în cadrul instituției noastre există puține informații care să descrie impactul infecției cu HIV asupra rezultatelor intervențiilor chirurgicale. Apendicita este cea mai frecventă urgență gastrointestinală, iar rezultatele chirurgicale ale acesteia în zonele cu prevalență mare a virusului HIV sunt descrise insuficient în literatura de specialitate. Aşadar, scopul acestui studiu este de a descrie şi a compara rezultatele apendicectomiei la pacienții infectați cu virusul HIV (HIV+) şi la cei neinfectați cu acest virus (HIV-).

Metode: Acesta este un studiu de cohortă de tip retrospectiv, pe o perioadă de 12 luni, cu pacienți care au fost supuşi apendicectomiei în cadrul unui spital regional. $\mathrm{Au}$ fost înregistrate date demografice, durata simptomelor înainte de internare, statutul HIV, abordarea chirurgicală, concluziile intervenției, rapoartele histopatologice, informații privitoare la şederea în spital şi complicațiile. Au fost descrise, analizate şi comparate datele referitoare la cohortele de pacienți HIV+ şi HIV-.

Rezultate: Grupul de studiu cuprinde 134 de pacienți; 18 (13,4\%) fiind infectați cu virusul HIV. Pacienții cu HIV+ sunt semnificativ mai în vârstă (vârsta medie de 29,3 față de 20,3 ani, $\mathrm{P}=0,002$ ) şi au prezentat simptome pentru o perioadă mai lungă de timp înaintea internării (medie de 3,94 vs. 2,57 zile, $\mathrm{P}=0,03$ ). 
Complicațiile postoperatorii $(44,4 \%$ față de $17,2 \%, \mathrm{P}=0,03)$ şi durata mai lungă a internării în spital (7,28 zile față de 5,95 zile, $\mathrm{P}=0,004)$ au fost de asemenea mai frecvent observate la pacienții cu HIV +. Nu au existat diferențe în ceea ce priveşte ratele de ruptură ale apendicelui, rezultatele histopatologice şi mortalitatea.

Concluzii: Pacienții HIV+ s-au prezentat mai târziu la spital, iar intervenția chirurgicală a fost asociată cu o rată mai ridicată a morbidității postoperatorii şi o perioadă mai lungă a internării.

Cuvinte cheie: apendicită, HIV/AIDS, rezultate, morbiditate, mortalitate

\section{Abstract}

Background: The high prevalence of Human Immunodeficiency Virus (HIV) has added a new dimension to the management and outcomes of many general surgical conditions in South Africa. However, there is a paucity of data describing the impact of HIV status on surgical outcomes in our setting. Appendicitis is a most common gastrointestinal emergency, and its surgical outcomes in areas of high HIV prevalence are poorly described in the literature. Thus, the aim of this study is to describe and compare the outcomes of appendectomy between HIV-infected (HIV+) and HIV-negative (HIV-) patients.

Methods: This is a retrospective cohort study of patients undergoing appendectomy at a large regional hospital over a 12-month period. Demographic data, duration of pre-hospital symptoms, HIV status, surgical approach, operative findings, histopathology reports, hospital stay and complications were recorded. Data for the HIV+ and HIV- patient cohorts were then described, analysed and compared.

Results: The study group comprised 134 patients; 18 (13.4\%) tested positive for HIV. HIV+ patients were significantly older (mean age of 29.3 vs. 20.3 years, $\mathrm{P}=0.002$ ) and had longer duration of pre-hospital symptoms (mean of 3.94 vs. 2.57 days, $\mathrm{P}=0.03$ ). Postoperative complications $(44.4 \%$ vs. $17.2 \%, \mathrm{P}=0.03$ ) and lengthier hospital stays (7.28 days vs. 5.95 days, $\mathrm{P}=0.004)$ were also more frequently seen in the HIV+ patients. There were no differences in appendiceal rupture rates, histopathological findings and mortality.

Conclusions: Presentation in HIV+ patients was delayed and surgery was associated with significant postoperative morbidity and longer hospital stay.

Key words: appendicitis, HIV/AIDS, outcomes, morbidity, mortality

\section{Background}

The Human Immune Deficiency Virus/ Acquired Immune Deficiency Syndrome (HIV/AIDS) pandemic has added a new dimension to the epidemiology, clinical presentation and outcomes of a wide array of general surgical conditions (1). South Africa has the highest number of people living with HIV globally; the national prevalence is $12 \%$ and 6.4 million people live with the disease. This study was conducted in the Northern Cape province, where the HIV prevalence is $7.4 \%$ (2).
This high national prevalence has also translated into surgical cohorts across the country. In the large multi-centre prospective South African Surgical Outcomes Study, Biccard et al (3) showed that $13.2 \%$ of patients undergoing surgery were HIV+.

Appendicitis is a very common Gastrointestinal (GIT) surgical emergency in the HIV+ (4-9). Green et al (10) recently showed that appendicitis was the cause of surgical sepsis in $26 \%$ of HIV+ patients. Opportunistic infections such as Tuberculosis (TB) and AIDS-related malignancies such as 
Kaposi's Sarcoma (KS) and lymphoma will frequently mimic the clinical presentation of appendicitis. Whilst an appendectomy will assist the surgeon in confirming the diagnoses and direct further therapy, the associated post-operative morbidity and mortality are concerning (1,4-9).

The effect of HIV infection on appendicitis and the surgical outcomes thereof have not been studied enough, there are only six published reports in the current literature. Paradoxically, only two of these publications are from SubSaharan Africa where HIV is highly prevalent $(4,6)$. The studies addressing surgical outcomes of appendicitis in HIV+ and HIV- patients are summarised in Table 1. Thus, the aim of this study is to describe and compare the outcomes of appendectomy between HIV-infected (HIV+) and HIV-negative (HIV-) patients.

\section{Patients and methods}

The Human Research Ethics Committee of the Faculty of Health Sciences at the University of Cape Town granted ethical approval for this study (HREC REF: 341/ 2015). Patients subjected to appendectomy following a clinical diagnosis of acute appendicitis from March 2010 to March 2011 at Kimberley Provincial Hospital were included in this retrospective study. Standard demographic information, time from onset of symptoms to hospital admission, HIV status, medical comorbidities, details of surgical approach, operative findings, histopathology reports, duration of Intensive Care Unit (ICU) admission, total hospital stay and post-operative complications were documented. When a patient was known to be HIV-infected, the CD4+ count and the HAART regimen were recorded.

\section{Surgical Approach}

Following initial assessment, a clinical diagnosis of acute appendicitis and informed consent, patients were taken for surgery. Prophylactic antibiotics were administered in all cases. Patients with localised right iliac fossa tenderness were approached through a McBurney or Lanz incision. An exploratory midline laparotomy was performed for generalized peritonitis. At the time of this study, laparoscopy had been newly introduced at Kimberley Provincial Hospital; laparoscopic appendectomy was thus attempted only in a limited number of cases. Conversion from a McBurney incision, Lanz incision or a laparoscopic approach to a laparotomy was necessary when diffuse peritonitis was noted intraoperatively or when the appendectomy could not be completely safely through the initial surgical approach. All resected appendixes were sent for histopathological assessment.

Table 1. Studies addressing surgical outcomes of appendicitis in HIV+ and HIV- patients

\begin{tabular}{|c|c|c|c|c|c|}
\hline Study & Year & Country & $\begin{array}{l}\text { Period } \\
\text { (years) }\end{array}$ & Number of patients & Significant Study findings \\
\hline Bova et al (5) & 1998 & Australia & 10 & $\begin{array}{l}\text { HIV- }(60) \\
\text { HIV }+(26)\end{array}$ & $\begin{array}{l}\text { Significant delay in presentation to hospital in the HIV + group } \\
\text { Higher post-operative morbidity rate in HIV+ group }\end{array}$ \\
\hline Giiti et al (6) & 2010 & Tanzania & 1 & $\begin{array}{l}\text { HIV- }(173) \\
\text { HIV }+(26)\end{array}$ & $\begin{array}{l}\text { HIV+ patients older and have less leukocytosis } \\
\text { Peritonitis more common in HIV+ group with increased rates of } \\
\text { Surgical Site Infection and lengthier hospital stay }\end{array}$ \\
\hline Masoomi et al (7) & 2015 & US & 3 & $\begin{array}{l}\text { HIV- }(572444) \\
\text { HIV }+(800)\end{array}$ & $\begin{array}{l}\text { Patients with AIDS had lengthier hospital stay, higher post-operative } \\
\text { complication and mortality rates } \\
\text { Laparoscopic appendectomy in AIDS patients has lower morbidity, } \\
\text { mortality and shorter hospital stay compared to open appendectomy }\end{array}$ \\
\hline Kitaoka et al (9) & 2015 & Japan & 6 & $\begin{array}{l}\text { HIV- }(212) \\
\mathrm{HIV}+(6)\end{array}$ & $\mathrm{CD}^{+}$count lower in HIV+ patients with complicated appendicitis \\
\hline Gigabhoy et al (4) & 2016 & South Africa & 1 & $\begin{array}{l}\text { HIV- }(36) \\
\text { HIV+ }+(14)\end{array}$ & Higher laparotomy rate in HIV + patients \\
\hline Smith et al (8) & 2016 & US & 8 & $\begin{array}{l}\text { HIV- }(337514) \\
\text { HIV+ }+(794)\end{array}$ & $\begin{array}{l}\text { Longer and more expensive hospital stay in AIDS patients } \\
\text { Higher risk of post-operative infections in AIDS patients }\end{array}$ \\
\hline
\end{tabular}




\section{Post-operative Care and Follow up}

Antibiotics were stopped within 48 hours of appendectomy for uncomplicated appendicitis and continued for five days in cases of rupture or diffuse peritonitis. HIV testing was offered to all patients; pre-test and post-test counseling were conducted irrespective of the test result. In the event of a positive result, the patient was immediately referred to the Infectious Diseases Clinic. On discharge from hospital, all patients were entered into a four-week follow-up program, and issued with a summary note detailing medical problems, treatment administered and a list of instructions to be followed. In particular, patients were advised to return to the unit immediately in the event of persistent abdominal pain, pyrexia and wound sepsis. Readmitted patients underwent complete clinical, biochemical and radiological evaluation as necessary.

Statistical analysis was performed using the Chi-Squaredor Fisher's exact test for noncontinuous variables, and non- parametric ANOVA and Wilcoxon ranked sum test for continuous variables. A $\mathrm{P}$ value less than $0 \cdot 05$ was considered statistically significant.

\section{Results}

One hundred and thirty-nine patients were subjected to appendectomy from March 2010 to March 2011. Five patients were excluded from the study; three did not consent to HIV testing and two had incomplete medical records.

The study sample thus comprised 134 patients. There were 86 males $(64.2 \%)$ and 48 females with a mean age of 21.5 years (range: 4 -64). Eighteen patients were HIV+; 16 were diagnosed during the present hospital admission and two patients were known to be HIV+ on HAART. A CD4+ count was available in 13 of these 16 patients; the mean count was 260 cells/ $\mu \mathrm{L}$ (range: 12 - 1129). HIV+ patients were older (mean age of 29.3 years vs. 20.3 years, $\mathrm{P}=0.002$ ) and experienced symptoms for longer (mean of 3.94 days vs. 2.57 days, $\mathrm{P}$ $=0.03$ ) before presenting to hospital (Table 2).
Table 2. Demographic and Clinical Characteristics of patients undergoing appendectomy during study

\begin{tabular}{|c|c|c|c|}
\hline $\begin{array}{l}\text { Demographic / } \\
\text { Clinical Characteristics }\end{array}$ & $\begin{array}{c}\text { HIV+ } \\
(n=18)\end{array}$ & $\begin{array}{c}\text { HIV- } \\
(n=116)\end{array}$ & $P$ Value \\
\hline \multicolumn{4}{|l|}{ Gender (number) } \\
\hline Male & 11 & 75 & - \\
\hline Female & 7 & 41 & \\
\hline \multicolumn{4}{|l|}{ Age (years) } \\
\hline Mean & 29.3 & 20.3 & 0.002 \\
\hline Range & $13-30$ & $4-64$ & \\
\hline \multicolumn{4}{|l|}{ Delay (days) } \\
\hline Mean & 3.94 & 2.57 & 0.003 \\
\hline Range & $0-14$ & $0-15$ & \\
\hline \multicolumn{4}{|l|}{ ICU Stay (days) } \\
\hline Mean & 1 & 3 & 0.71 \\
\hline Range & $1-1$ & $3-6$ & \\
\hline \multicolumn{4}{|l|}{ Total Hospital Stay (days) } \\
\hline Mean & 7.28 & 5.95 & 0.004 \\
\hline Range & $3-19$ & $1-53$ & \\
\hline \multicolumn{4}{|l|}{ Mortality } \\
\hline Number & 1 & 2 & $>0.05$ \\
\hline Rate (\%) & 5.56 & 1.72 & \\
\hline
\end{tabular}

There was no difference in the signs and symptoms experienced by both patient groups (Table 3).

A laparotomy was more frequently performed in the HIV+ patient $(72.2 \%$ vs. $41.3 \%$, $\mathrm{P}=0.03$ ) (Table 4). The postoperative complication rate was higher in $\mathrm{HIV}+$ patients ( $44.4 \%$ vs. $17.2 \%, \mathrm{P}=0.03)$; the predominant complication was Surgical Site Infection (SSI) (Table 5). There was no difference in the mortality. Although the total hospital stay was longer for HIV+ patients (7.28 days vs. 5.95 days, $\mathrm{P}=0.004)$, ICU stay was similar in both patient groups.

The appendiceal perforation rates and negative appendectomy rates were similar in

Table 3. Individual clinical and haematological characteristics in HIV- and HIV+ patients

\begin{tabular}{|c|c|c|c|}
\hline $\begin{array}{l}\text { Clinical and Laboratory } \\
\text { Parameters }\end{array}$ & $\begin{array}{c}\text { HIV + }(n=18) \\
N(\%)\end{array}$ & $\begin{array}{c}\text { HIV- }(n=116) \\
\text { N (\%) }\end{array}$ & P Value \\
\hline \multicolumn{4}{|l|}{ Symptoms } \\
\hline Migratory Right lliac Fossa Pain & $67(58)$ & $13(72)$ & \\
\hline Nausea / Vomiting & $95(83)$ & $16(89)$ & \\
\hline Anorexia & $96(83)$ & $15(83)$ & \\
\hline \multicolumn{4}{|l|}{ Signs } \\
\hline Right lower quadrant pain & $108(94)$ & $17(94)$ & $>0.05$ \\
\hline Rebound tenderness & $86(75)$ & $16(89)$ & \\
\hline Elevated temperature & $64(56)$ & $11(61)$ & \\
\hline \multicolumn{4}{|l|}{ Laboratory Findings } \\
\hline Leucocytosis & $93(81)$ & $11(61)$ & \\
\hline
\end{tabular}


Table 4. Surgical approaches in HIV+ and HIV- patient cohorts

\begin{tabular}{|c|c|c|}
\hline Surgical Approach & $\begin{array}{l}\text { HIV+ }(\mathrm{n}=18) \\
\text { Number }(\%)\end{array}$ & $\begin{array}{l}\text { HIV- }(\mathrm{n}=116) \\
\text { Number }(\%)\end{array}$ \\
\hline \multicolumn{3}{|l|}{ Minor } \\
\hline McBurney Incision & $4(22.2)$ & $44(37.9)$ \\
\hline Lanz Incision & 0 & $17(14.7)$ \\
\hline Laparoscopic & $1(5.56)$ & $6(5.17)$ \\
\hline $\begin{array}{l}\text { Laparoscopic converted } \\
\text { to McBurney Incision }\end{array}$ & 0 & $1(0.862)$ \\
\hline Total & $5(27.8)$ & $68(58.7)$ \\
\hline \multicolumn{3}{|l|}{ Major } \\
\hline Laparotomy & $11(61.1)$ & $41(35.3)$ \\
\hline $\begin{array}{l}\text { McBurney Incision converted } \\
\text { to laparotomy }\end{array}$ & 0 & $5(4.31)$ \\
\hline $\begin{array}{l}\text { Lanz Incision converted to } \\
\text { laparotomy }\end{array}$ & 0 & $2(1.72)$ \\
\hline $\begin{array}{l}\text { Laparoscopic converted } \\
\text { to laparotomy }\end{array}$ & $2(11.1)$ & 0 \\
\hline Total & $13(72.2)$ & $48(41.3)$ \\
\hline P Value & \multicolumn{2}{|c|}{0.03} \\
\hline
\end{tabular}

the HIV+ and HIV- groups, $38.9 \%$ vs. $31.0 \%$ $(\mathrm{P}=0.69)$ and $27.8 \%$ vs. $12.9 \% \quad(\mathrm{P}=0.20)$ respectively.

\section{Discussion}

The HIV/AIDS pandemic has significantly impacted upon the South African surgical landscape. Atypical presentations and outcomes associated with increased morbidity and mortality are now well recognized amongst many general surgical conditions (1).

This study was conducted in the Northern Cape province of South Africa, where the HIV prevalence is $7.4 \%$ (2). An HIV seroprevalence of $13.4 \%$ in this cohort of patients is not negligible and is comparable to data from other Sub-Saharan centres. Gigabhoy et al (4) recently showed that the HIV prevalence in patients undergoing appendectomy at a large tertiary urban hospital is $28 \%$. In a Tanzanian study conducted at a major referral centre, the prevalence was found to be $13.1 \%$ (6). These results support the theory that HIV status may be a risk factor for appendicitis $(11,12)$. Crum-Cianflone and colleagues (12) propose that biological and epidemiological factors account for this observation. HIV seropositivity imparts an increased risk of developing appendicitis because the fragile vasculature of
Table 5. Complications documented in HIV- and HIV+ patient cohorts

\begin{tabular}{llc}
\hline $\begin{array}{l}\text { HIV } \\
\text { Status }\end{array}$ & $\begin{array}{l}\text { Post-operative } \\
\text { Complications }\end{array}$ & $\begin{array}{c}\text { Number of Complications } \\
\text { (\%) }\end{array}$ \\
\hline HIV + & Surgical Site Infection & 3 \\
$(n=18)$ & Persistent Post-operative Pyrexia & 2 \\
& Intraabdominal Abscess & 1 \\
& Septic Shock & 1 \\
\hline & Morbidity Rate & $7 / 18(38.9 \%)$ \\
\hline HIV- & Surgical Site Infection & 9 \\
$(n=116)$ & Intraabdominal Abscess & 3 \\
& Ileus & 2 \\
& Septic Shock & 2 \\
& Nosocomial Pneumonia & 1 \\
\hdashline & Morbidity Rate & $17 / 116(14.7 \%)$ \\
\hline P Value & & 0.03 \\
\hline
\end{tabular}

the appendix is more predisposed to disease. Furthermore, opportunistic infections and IRIS secondary to HAART render HIV+ patients more prone to developing appendicitis (13).

The mean age was significantly higher in the HIV+ group than in the seronegative patients (29.3 vs. 20.3 years). This finding is echoed in both papers emanating from Africa, $(4,6)$ which suggest that the HIV+ patient develops appendicitis at a more advanced age. A large study that interrogated the Nationwide Inpatient Sample (NIS) in the US also showed that AIDS patients undergoing appendectomy were significantly older than the control group (8).

A CD4+ count was recorded in $81 \%$ (13 patients); the mean value was 260 cells/ $/ \mathrm{L}$. Because of the small subgroup numbers, it was not statistically feasible to correlate the CD4+ count with appendiceal perforation or post-operative morbidity and mortality. A Viral Load (VL) was not routinely performed for budgetary reasons. In our setting, the VL is used to gauge therapeutic response to HAART and determine the presence of viral resistance. Establishing whether CD4+count or VL should be routinely done in the HIV+ undergoing abdominal surgery has been a futile endeavour so far. We remain unconvinced of their use as surgical prognosticators since the literature comprises mainly of retrospective series with conflicting results (14-18). Some studies show higher morbidity with advanced 
clinical stages of the disease $(1,14,15)$, whilst others conclude there is no difference (16). In a prospective cohort study, ČaČala et al (16) showed that HIV status did not influence the outcome of general surgical procedures, and CD4+ count was not a prognosticator of total hospital stay, hospital mortality and severity of post-operative sepsis. However, in a recent large retrospective study investigating the effects of HIV status on the outcomes of surgical sepsis, Green et al (6) determined that there was a significantly higher mortality of $60 \%$ in patients who had a CD $4+$ count $<200$ cells $/ \mu \mathrm{l}$ versus $2 \%$ in the CD $4+$ count $>200$ cells/ $\mu$ l group. In emergency surgery patients, a lower CD4+ count is associated with increased post-operative septic complications and longer hospital stay $(14,15,17,19)$. Xia et al (15) have gone on to further suggest that a CD4/CD8 ratio $\leq 0.15$ is a useful predictor of post-operative sepsis in $\mathrm{HIV}+$ patients undergoing major abdominal surgery.

Delayed presentation to hospital occurred more frequently in the HIV+ patient cohort (3.94 vs. 2.57 days, $\mathrm{P}=0.03$ ). Failure to mount an immune response can manifest clinically by the absence of pyrexia and abdominal signs in early appendicitis. Localised right iliac fossa tenderness is not common in those infected with the virus (4) and pre-operative leukocytosis is also less frequently observed (6). Many have suggested that the absence of these clinical signs, symptoms and laboratory findings contribute to the delay in hospital presentation, and the subsequent higher morbidity. Although the delay in presentation is well documented in this study, there were no differences in the clinical signs and symptoms exhibited by both patient groups.

A recent systematic review conducted by Yang et al confirmed that appendicitis trends in South Africa are consistent with those seen in other newly industrialised countries (20). However, appendicitis in South Africa has a far more serious clinical course when compared to developed countries, mainly because of longer delays ingetting definitive surgical care. A high perforation rate of $36 \%$ and the need for laparotomy in $18 \%$ to $60 \%$ of patients drive the high post-operative morbidity (21). The laparotomy rate was higher in HIV+ patients $(72.2 \%$ vs. $41.3 \%, \mathrm{P}=0.03)$. Previous authors have ascribed this operative approach to the high rate of perforation and peritonitis, that occurdue to the delay in presentation of these patients $(4,6)$. The morbidity relates predominantly to Surgical Site Infections, and is reduced with a laparoscopic approach $(7,8)$. The post-operative morbidity was higher in those infected with the virus $(38.9 \%$ vs. $14.7 \%$, $\mathrm{P}=0.03)$ in this study. SSI was the most common complication and septic shock was documented in a single patient. These findings are in keeping with previous studies that have investigated the effect of HIV on appendicitis (5-8). In spite of these correlations, the impact of the HIV pandemic on surgical outcomes remains controversial; there are no prospective trials in the current literatureand most retrospective studies are small and yielded conflicting results (1,22-24). Early reports showed high mortality rates of $55 \%$ to $70 \%$ in AIDS patients undergoing emergency surgery. Based on the data available then, surgeons tended to be more conservative with HIV+ patients and avoided major surgical interventions. However, there is now emerging evidence to suggest that the post-operative morbidity and mortality in HIV+ patients compare favourably to HIV- patients, and that the standard surgical therapy should be equally afforded to both groups $(25,26)$.

There was a single mortality in the HIV+ group. This was a 26-year-old pregnant woman who had a laparotomy for perforated appendicitis in the presence of abdominal TB. She was ventilated for one day in the ICU and demised of septic shock. The two deaths in the HIV- were also attributed to septic shock secondary to diffuse peritonitis. The mortality was similar in both patient cohorts. Whether HIV+ patients undergoing emergency abdominal surgery are at risk for increased mortality is still highly debatable. A careful literature search yielded contradictory data with regards to mortality. There is some data to suggest that anorectal procedures are predisposed to poorer outcomes, and late mortality is related 
to the progression of HIV infection rather than the primary surgical pathology (27-29). Irrespective of aetiology, GIT bleeding is another poor prognosticator of both in-hospital and long-term mortality (30,31).

Following major abdominal surgery, HIV+ patients should be considered for ICU care. In a South African study, Bhagwanjee et al (25) showed no increase in the ICU and total hospital stay, albeit the higher incidence of septic shock in HIV+ patients. Predictors of long-term survival after ICU admission include mechanical ventilation and albumin levels (26).

Post appendectomy, the HIV+ patients stayed longer in hospital (7.28 vs. 5.95 days, $\mathrm{P}=0.004)$; an observation made by two large national database studies previously $(7,8)$. The length of hospital stay in this study relates mainly to the post-operative complications of SSIs and persistent pyrexia. Cases of SSIs were managed in hospital until all wounds were fully consolidated. This is mainly because of the geography of the Northern Cape province; a large number of our patients come from rural areas and access to healthcare facilities can be difficult.

A prolonged post-operative pyrexia was noted in two HIV+ patients; the septic work- up was negative in both. It is interesting to note that previous authors have made similar observations but could not assign a specific aetiology to them $(6,12)$.

\section{Conclusion}

This retrospective study investigates the effect of HIV status on the surgical outcomes of appendectomy in the Northern Cape Province of South Africa. The HIV prevalence in those undergoing appendectomy in South Africa is 13.4\%. These patients present in a delayed fashion to hospital and require more extensive surgery than their seronegative counterparts. Findings of higher post-operative complication rates in those infected in the virus are in keeping with previous reports. The effect of CD4+ count, VL and Clinical Stage on surgical outcome is still controversial. It is vital to understand that this study was conducted in a single province of South Africa where the HIV prevalence is $7.4 \%$. It only provides a snapshot of the effect of HIV on a common GIT surgical emergency. Although the current data does provide some direction regarding the issue, there is need for a large multi-centre prospective study in Sub-Saharan Africa to investigate the effect of HIV status on the surgical outcomes of appendicitis.

\section{Ethics Approval and Consent to Participate}

The Human Research Ethics Committee of the Faculty of Health Sciences at the University of Cape Town (Federal Wide Assurance Number: FWA00001637, Institutional Review Board number: IRB00001938) granted ethical approval for this study ( HREC REF: 341/2015).

\section{Consent for Publication: Not applicable.}

\section{Availability of Data and Materials}

Please contact authors for data requests.

\section{Authors' Contributions}

SS,CE and DK designed the study and drafted the manuscript. $\mathrm{AB}$ and JK performed the study analysis and drafted the manuscript. GV performed all the histopathological analyses and drafted the manuscript.

Acknowledgements: Not applicable

Funding: No funding was required for this study.

\section{Conflicts of Interest: None}

\section{References}

1. Rose DN, Collins M, Kleban R. Complications of surgery in HIV-infected patients. Aids. 1998;12(17):2243-51.

2. Shisana O, Rehle T, Simbayi LC, Zuma K, Jooste S, Zungu N, Labadarios D, Onoya D. South African national HIV prevalence, incidence and behaviour survey, 2012. Cape Town: HSRC Press. 2014.

3. Biccard BM, Madiba TE. The South African Surgical Outcomes 
Study: a 7-day prospective observational cohort study. South African Medical Journal. 2015;105(6):465-75.

4. Gigabhoy R, Cheddie S, Singh B. Appendicitis in the HIV Era: a South African perspective. Indian Journal of Surgery. 2016:1-4.

5. Bova R, Meagher A. Appendicitis in HIV-positive patients. ANZ Journal of Surgery. 1998;68(5):337-9.

6. Giiti GC, Mazigo HD, Heukelbach J, Mahalu W. HIV, appendectomy and postoperative complications at a reference hospital in Northwest Tanzania: cross-sectional study. AIDS research and therapy. 2010;7(1):47.

7. Masoomi H, Mills SD, Dolich MO, Dang P, Carmichael JC, Nguyen NT, et al. Outcomes of laparoscopic and open appendectomy for acute appendicitis in patients with acquired immunodeficiency syndrome. Am Surg. 2011 77(10):1372-6.

8. Smith MC, Chung PJ, Constable YC, Boylan MR, Alfonso AE, Sugiyama G. Appendectomy in patients with human immunodeficiency virus: Not as bad as we once thought. Surgery. 2017; 161(4):1076-1082.

9. Kitaoka K, Saito K, Tokuuye K. Significance of CD4+ T-cell count in the management of appendicitis in patients with HIV. Canadian Journal of Surgery. 2015;58(6):429.

10. Green S, Kong VY, Odendaal J, Sartorius B, Clarke DL, Brysiewicz $P$, et al. The effect of HIV status on clinical outcomes of surgical sepsis in KwaZulu-Natal Province, South Africa. S Afr Med J. 2017; 107(8):702-705

11. Klein DB, Hurley LB, Horberg MA, Silverberg MJ, Follansbee SE, Flamm JA, et al. Increased Rates of Appendicitis in HIV-Infected Men: 1991-2005. J Acquir Immune Defic Syndr. 2009;52(1): 139-40.

12. Crum-Cianflone N, Weekes J, Bavaro M. Appendicitis in HIVinfected patients during the era of highly active antiretroviral therapy. HIV medicine. 2008;9(6):421-6.

13. Aldeen T, Horgan M, Macallan DC, Thomas V, Hay P. Is acute appendicitis another inflammatory condition associated with highly active antiretroviral therapy (HAART)? HIV medicine. 2000; 1(4):252-5.

14. Chichom-Mefire A, Azabji-Kenfack M, Atashili J. CD4 count is still a valid indicator of outcome in HIV-infected patients undergoing major abdominal surgery in the era of highly active antiretroviral therapy. World journal of surgery. 2015;39(7):1692-9.

15. Xia XJ, Liu BC, Su JS, Pei H, Chen H, Li L, et al. Preoperative CD4 count or CD4/CD8 ratio as a useful indicator for postoperative sepsis in HIV-infected patients undergoing abdominal operations. J Surg Res. 2012;174(1):e25-30.

16. Cacala SR, Mafana E, Thomson SR, Smith A. Prevalence of HIV status and CD4 counts in a surgical cohort: their relationship to clinical outcome. Ann R Coll Surg Engl. 2006;88(1):46-51.

17. Davis PA, Corless DJ, Gazzard BG, Wastell C. Increased risk of wound complications and poor healing following laparotomy in HIV-seropositive and AIDS patients. Digestive surgery. 1999; 16(1):60-7.

18. Weledji EP, Nsagha D, Chichom A, Enoworock G. Gastrointestinal surgery and the acquired immune deficiency syndrome. Annals of medicine and surgery. 2015 Mar 31;4(1):36-40.

19. Feng $T$, Feng $X$, Jiang $C$, Huang $C$, Liu B. Sepsis risk factors associated with HIV-1 patients undergoing surgery. Emerging microbes \& infections. 2015;4(9): e59.

20. Yang E, Kahn D, Cook C. Acute appendicitis in South Africa: a systematic review. South African Journal of Surgery. 2015;53(34):1-8.

21. Kong VY, Bulajic B, Allorto NL, Handley J, Clarke DL. Acute appendicitis in a developing country. World journal of surgery. 2012;36(9):2068-73.

22. Morino G, Baldan M, D’Onofrio E, Melotto A, Bertolaccini L. AIDS and surgery. East and Central African Journal of Surgery. 2004:9(2):9-11.

23. Vallabha T, Dhamangaonkar M, Sindgikar V, Nidoni R, Biradar H, Kv $A$, et al. Clinical Profile of Surgical Diseases with Emergence of New Problems in HIV+ Individuals. Indian J Surg. 2017; 79(1):29-32.

24. Kosmidis C, Anthimidis G, Vasiliadou K. Acute Abdomen and HIV Infection. In HIV Infection in the Era of Highly Active Antiretroviral Treatment and Some of Its Associated Complications 2011. InTechoper.com

25. Bhagwanjee S, Muckart DJ, Jeena PM, Moodley P. Does HIV status influence the outcome of patients admitted to a surgical intensive care unit? A prospective double-blind study. BMJ. 1997; 314(7087):1077.

26. Moodley Y, Govender K. An HIV-positive status and short term perioperative mortality-a systematic review. Southern African Journal of Infectious Diseases. 2017;32(1):12-6.

27. Morandi E, Merlini D, Salvaggio A, Foschi D, Trabucchi E. Prospective study of healing time after hemorrhoidectomy. Diseases of the colon \& rectum. 1999;42(9):1140-4.

28. Lord RV. Anorectal surgery in patients infected with human immunodeficiency virus: factors associated with delayed wound healing. Annals of surgery. 1997;226(1):92.

29. Safavi A, Gottesman L, Dailey TH. Anorectal surgery in the HIV+ patient: update. Diseases of the colon \& rectum. 1991;34(4): 299304.

30. Parente F, Cernuschi M, Valsecchi L, Rizzardini G, Musicco M, Lazzarin A, et al. Acute upper gastro-intestinal bleeding in patients with AIDS: a relatively uncommon condition associated with reduced survival. Gut. 1991;32(9):987-90.

31. Chalasani N, Wilcox CM. Etiology and outcome of lower gastrointestinal bleeding in patients with AIDS. The American journal of gastroenterology. Am J Gastroenterol. 1998;93(2):175-8. 